This is an electronic reprint of the original article. This reprint may differ from the original in pagination and typographic detail.

Author(s): Peuronen, Anssi; Lehtonen, Ari

Title: $\quad$ Dioxomolybdenum(VI) and -Tungsten(VI) Amino Bisphenolates as Epoxidation Catalysts

Year: $\quad 2016$

Version:

Please cite the original version:

Peuronen, A., \& Lehtonen, A. (2016). Dioxomolybdenum(VI) and-Tungsten(VI) Amino Bisphenolates as Epoxidation Catalysts. Topics in Catalysis, 59(13), 1132-1137. https://doi.org/10.1007/s11244-016-0632-9

All material supplied via JYX is protected by copyright and other intellectual property rights, and duplication or sale of all or part of any of the repository collections is not permitted, except that material may be duplicated by you for your research use or educational purposes in electronic or print form. You must obtain permission for any other use. Electronic or print copies may not be offered, whether for sale or otherwise to anyone who is not an authorised user. 


\title{
Dioxomolybdenum(VI) and -tungsten(VI) amino bisphenolates as epoxidation catalysts
}

\author{
Anssi Peuronen, ${ }^{1}$ Ari Lehtonen ${ }^{2 *}$ \\ ${ }^{1}$ Laboratory of Inorganic Chemistry, Department of Chemistry, University of Jyväskylä, FI- \\ 40014 Jyväskylä, Finland \\ ${ }^{2}$ Laboratory of Materials Chemistry and Chemical Analysis, Department of Chemistry, \\ University of Turku, FI-20014, Turku, Finland. \\ * Corresponding author \\ ari.lehtonen@utu.fi
}

Fax: +358-2-333 6700

Tel: +358-2-333 6733

\begin{abstract}
Low-cost metallate salts $\mathrm{Na}_{2} \mathrm{MO}_{4} \cdot 2 \mathrm{H}_{2} \mathrm{O}(\mathrm{M}=$ molybdenum, tungsten $)$ react with a tridentate amine bisphenol bis(2-hydroxy-3-tert-butyl-5-methylbenzyl)methylamine $\left(\mathrm{H}_{2} \mathrm{ONO}^{\mathrm{tBu}}\right)$ under ambient conditions in acidic methanol solutions. The reactions lead to the formation of isostructural dioxo complexes $\left[\mathrm{MO}_{2}\left(\mathrm{ONO}^{\mathrm{tBu}}\right)(\mathrm{MeOH})\right] \cdot \mathrm{MeOH}$ in convenient yields. Spectral data as well as $\mathrm{X}$-ray analyses reveal these complexes to be isostructural. Both compounds were tested as catalysts for epoxidation of olefins using ciscyclooctene, cyclohexene, norbornene and styrene as substrates and tert-butyl hydroperoxide and hydrogen peroxide as oxidants. The molybdenum complex catalyses selectively the oxidation of cis-cyclooctene and norbornene to corresponding epoxides, whereas oxidation of cyclohexene and styrene lead low yields as the epoxidations were associated with the formation of other oxidation products. Corresponding tungsten complex shows lower activity for epoxidation of norbornene and practically no activity for other olefins. Both complexes can also catalyse the conversion of benzoin to benzil using dimethyl sulphoxide as an oxidant, while the molybdenum complex shows higher activity.
\end{abstract}

\section{KEYWORDS}

Molybdenum complexes, tungsten complexes, tridentate ligands, epoxidation, catalysis 


\section{Introduction}

Molybdenum and tungsten are found in nature as water-soluble and biologically available high-valent oxo species. These metals are found in a variety of metalloenzymes that take part in oxygen atom transfer (OAT) reactions. In such reactions, an oxygen atom is transferred from an oxygen donor to a biologically relevant acceptor molecule or vice versa [1-5]. Considering these important biological functions, many examples of molybdenum- and tungsten-containing model compounds for OAT have been studied [6-10]. Similarly, a number of artificial dioxomolybdenum(VI) and -tungsten(VI) complexes have been prepared for catalytic applications in important industrial processes, for example olefin epoxidation [11-13]. Such complexes can be also considered as soluble molecular models for metal oxide catalysts [14]. As group 6 d-block metals, Mo and W are rather similar elements in regard to their occurrence, metallurgy and physical properties [15]. In addition, they share many chemical properties and are able to form structurally identical compounds. However, there are also remarkable differences between these two metals, thus compounds of the same structural type may differ noticeably in their formation, reactions and biochemical function. This is clearly seen, for example, when comparing the properties of Moenzymes with those of their W-substituted analogues. For example, W can replace Mo in sulphite oxidase or nitrate reductase at the same coordination site but with remarkable differences in their behaviour, as these enzymes are less active or completely inactive upon the substitution of Mo by W [16-18]. Dioxomolybdenum(VI) complexes with amine bisphenol ligands have generally been prepared from stable and easily available $\mathrm{MoO}_{2}(\mathrm{acac})_{2}$ or $\mathrm{MoO}_{2} \mathrm{Cl}_{2}$ and relevant ligand precursors in high yields using simple ligand displacement reactions [19-26], whereas occasional examples employ the use of an acidic solution of $\left(\mathrm{NH}_{4}\right)_{6} \mathrm{Mo}_{7} \mathrm{O}_{24} \cdot 4 \mathrm{H}_{2} \mathrm{O}$ [27-29]. Corresponding W compounds are made under dry conditions using $\left[\mathrm{WO}_{2} \mathrm{Cl}_{2}(\mathrm{dme})\right]$ and ligands as free bases or sodium salts [30,31] or mixing free ligands and $\left[\mathrm{W}(\mathrm{eg})_{3}\right]$ (eg = ethylene glycol) in alcohol solutions in the presence of ambient moisture $[19,32]$. We have previously prepared a molybdenum complex $\left[\mathrm{MoO}_{2}\left(\mathrm{ONO}^{\mathrm{tBu}}\right)(\mathrm{MeOH})\right] \cdot \mathrm{MeOH}(\mathrm{Mo1})$ $\left(\mathrm{H}_{2} \mathrm{ONO}^{\mathrm{tBu}}=\right.$ bis(2-hydroxy-3-tert-butyl-5-methylbenzyl)methylamine) using $\mathrm{MoO}_{2}(\mathrm{acac})_{2}$ as a starting material [19]. In the present study, stable and low-cost metallate salts, $\mathrm{Na}_{2} \mathrm{MO}_{4} \cdot 2 \mathrm{H}_{2} \mathrm{O}(\mathrm{M}=\mathrm{Mo}$, W) were used to prepare Mo1 and its tungsten analogue $\left[\mathrm{WO}_{2}\left(\mathrm{ONO}^{\mathrm{tBu}}\right)(\mathrm{MeOH})\right] \cdot \mathrm{MeOH}$ W1. These complexes were tested as catalysts for epoxidation of olefins cis-cyclooctene, cyclohexene, norbornene and styrene using tert-butyl hydroperoxide (TBHP) as an oxidant.

\section{Experimental}

All syntheses and manipulations were done under an ambient atmosphere. Solvents (HPCL grade) were used as received. Ligand precursor $\mathrm{H}_{3} \mathrm{ONO}^{\mathrm{tBu}}$ was synthesised applying slight modification of a published procedure [33]. 
TBHP was purified by vacuum distillation prior to use. CAUTION: a mixture of TBHP with organic compounds is potentially explosive. All other chemicals and solvents were reagent grade, available commercially and used as received. The IR spectra were measured with Bruker Optics, Vertex 70 device with a diamond ATR setup. The ${ }^{1} \mathrm{H}$ spectra were recorded with Bruker Avance $500\left({ }^{1} \mathrm{H}: 500.13 \mathrm{MHz}\right)$ NMR spectrometer.

Preparation of complexes: Metal precursors $\mathrm{Na}_{2} \mathrm{MO}_{4} \cdot 2 \mathrm{H}_{2} \mathrm{O}(1.0 \mathrm{mmol}, \mathrm{M}=\mathrm{Mo}: 0.29 \mathrm{~g}$; W: $0.38 \mathrm{~g})$ and ligand ( $1.0 \mathrm{mmol}, 0.38 \mathrm{~g}$ ) were dissolved in $20 \mathrm{ml}$ of $\mathrm{MeOH}$ and $0.2 \mathrm{ml}$ of acetic acid was added. The reaction mixtures were refluxed for two hours, cooled and then kept overnight at room temperature (Mo1) or at $5{ }^{\circ} \mathrm{C}$ (W1). The products were isolated as large crystals by filtration and washed with a small amount of cold methanol.

$\left[\mathrm{MoO}_{2}\left(\mathrm{ONO}^{\mathrm{tBu}}\right)(\mathrm{MeOH})\right] \cdot \mathrm{MeOH}$ Mo1: $380 \mathrm{mg}(63 \%)$ of yellow crystals. IR: 3333m, 3147w, 2951m, 2907w, 2860w, 1607w, 1550w, 1530w, 1513w, 1478m 1469m, 1445m, 1414m, 1389m, 1358w, 1313w, 1288w, 1252m, 1240s, 1229s, 1211m, 1146m, 1096m, 1028m, 1018s, 987w, 940m, 916w, 887s, 862s, 837vs, 798w, 770w, 762m, 681w, 596w, 569vs, 559s, 538w, 513w, 492w, 474w. ${ }^{1} \mathrm{H}$ NMR (DMSO-d 6 ): $\delta_{\mathrm{H}} 6.97$ (d, $\left.J=1.8 \mathrm{~Hz}, 2 \mathrm{H}, \mathrm{ArH}\right), 6.82$ (d, $J=1.8 \mathrm{~Hz}, 2 \mathrm{H}, \mathrm{ArH}), 4.39\left(\mathrm{~d}, J=12.1 \mathrm{~Hz}, 2 \mathrm{H}, \mathrm{NCH}_{2}\right), 3.17\left(\mathrm{~s}, 6 \mathrm{H}, \mathrm{CH}_{3} \mathrm{OH}\right), 2.91(\mathrm{~d}, J=14.0,2 \mathrm{H}, \mathrm{NCH})$, $2.20\left(\mathrm{~s}, 6 \mathrm{H}, \mathrm{ArCH}_{3}\right), 2.08\left(\mathrm{~s}, 3 \mathrm{H}, \mathrm{NCH}_{3}\right), 1.35\left(\mathrm{~s}, 18 \mathrm{H}, \mathrm{C}\left(\mathrm{CH}_{3}\right)_{3}\right)$. Anal. calcd. for $\mathrm{C}_{27} \mathrm{H}_{43} \mathrm{MoNO}_{6}(\mathrm{MW}=573.60$ g.mol ${ }^{-1}$ ): C 56.54; H 7.56; N 2.44; found: C 56.15; H 7.50; N 2.43.IR and NMR spectra were essentially identical to those reported earlier by us [19].

$\left[\mathrm{WO}_{2}\left(\mathrm{ONO}^{\mathrm{tBu}}\right)(\mathrm{MeOH})\right] \cdot \mathrm{MeOH}$ W1: $0.35 \mathrm{~g}(53 \%)$ of colourless crystals. IR: 3221m, 3086w, 2953m, 2908w, 2868w, 2814w, 1604w, 1550w, 1530w, 1512w, 1478m, 1469m, 1445m, 1416m, 1391m, 1358w, 1315w, 1290w, 1254m, 1240s, 1229s, 1211m, 1146m, 1092w, 1032m, 1013s, 987w, 957m, 937w, 916w, 893s, 860s, 839vs, 798w, 770w, 760m, 681w, 596w, 569vs, 559s, 536w, 513w, 494w, 478w. ${ }^{1} \mathrm{H}$ NMR (DMSO-d $): \delta_{\mathrm{H}} 7.02(\mathrm{~d}, J=1.8 \mathrm{~Hz}$, $2 \mathrm{H}, \mathrm{ArH}), 6.83(\mathrm{~d}, J=1.8 \mathrm{~Hz}, 2 \mathrm{H}, \mathrm{ArH}), 4.44(\mathrm{~d}, J=12.4 \mathrm{~Hz}, 2 \mathrm{H}, \mathrm{NCH}), 3.16\left(\mathrm{~s}, 6 \mathrm{H}, \mathrm{CH}_{3} \mathrm{OH}\right), 3.01(\mathrm{~d}, J=12.0$, $\left.2 \mathrm{H}, \mathrm{NCH}_{2}\right), 2.22\left(\mathrm{~s}, 6 \mathrm{H}, \mathrm{ArCH}_{3}\right), 2.14\left(\mathrm{~s}, 3 \mathrm{H}, \mathrm{NCH}_{3}\right), 1.35\left(\mathrm{~s}, 18 \mathrm{H}, \mathrm{C}\left(\mathrm{CH}_{3}\right)_{3}\right)$. Anal. calcd. for $\mathrm{C}_{27} \mathrm{H}_{43} \mathrm{WNO}_{6}\left(\mathrm{MW}^{2}\right.$ $=661.48$ g.mol $\left.{ }^{-1}\right):$ C 49.03; H 6.55; N 2.12; found: C 48.88; H 6.84; N 2.11.

Single crystals of W1 were obtained from a reaction mixture and the X-ray data was collected and analysed according to the procedure reported earlier by our group [34]. Crystallographic data for W1: formula $\mathrm{C}_{27} \mathrm{H}_{43} \mathrm{NO}_{6} \mathrm{~W}$, $\mathrm{Mr}=661.47$, monoclinic, space group $\mathrm{P} 2{ }_{1} / \mathrm{c}, \mathrm{a}=12.6357(3), \mathrm{b}=14.7758(4), \mathrm{c}=15.7124(3) \AA, \beta=101.2346(12)^{\circ}$, $\mathrm{Z}=4, \mathrm{~V}=2877.33(12) \AA^{3}, \mathrm{~T}=170 \mathrm{~K}, \rho_{\mathrm{c}}=1.527 \mathrm{~g} \mathrm{~cm}^{-3}, \mathrm{~F}(000)=1336.0, \mu($ Mo-K $\alpha)=4.053 \mathrm{~mm}^{-1}, 15396$ data, 5621 unique $\left(\mathrm{R}_{\text {int }}=0.0326\right), 333$ parameters, final $\mathrm{R}_{1}(\mathrm{I}>2 \sigma(\mathrm{I}))=0.0344, w \mathrm{R}_{2}=0.0682, \mathrm{GOF}=1.069 . \mathrm{CCDC}$ 1431928 contains the supplementary crystallographic data for W1. These data can be obtained free of charge via 
http://www.ccdc.cam.ac.uk/conts/retrieving.html, or from the Cambridge Crystallographic Data Centre, 12 Union Road, Cambridge CB2 1EZ, UK; fax: (+ 44) 1223-336-033; or e-mail: deposit@ccdc.cam.ac.uk.

Catalytic activities. The epoxidations of cis-cyclooctene (S1), cyclohexene (S2), norbornene (S3) and styrene (S4) were run in the screw-cap vials under ambient atmosphere. A sample of a catalyst (7.1 $\mu$ mol, Mo1: $4.1 \mathrm{mg}$ or W1: $4.7 \mathrm{mg}$ ) was suspended in a mixture of TBHP $(3.0 \mathrm{mmol}, 0.29 \mathrm{ml})$, olefin $(1.5 \mathrm{mmol}, \mathbf{S 1}: 0.20 \mathrm{ml}$; S2: $0.15 \mathrm{ml}$; S3: $0.14 \mathrm{~g} ; \mathbf{S 4 :} 0.17 \mathrm{ml})$ and $1,2-\mathrm{C}_{2} \mathrm{H}_{4} \mathrm{Cl}_{2}(0.2 \mathrm{ml})$ to have an oxidant:olefin:catalyst ratio of 420:210:1. The reaction mixtures were kept at $60{ }^{\circ} \mathrm{C}$ for 2 hours and subsequently analysed by ${ }^{1} \mathrm{H}$ NMR. In some experiments, the epoxidations of cis-cyclooctene and norbornene were studied using corresponding amounts of $\mathrm{H}_{2} \mathrm{O}_{2}(3.0 \mathrm{mmol}$, $0.34 \mathrm{ml}$ of $30 \%$ solution in water) as an oxygen source. The epoxidations of cis-cyclooctene and norbornene were also followed by ${ }^{1} \mathrm{H}$ NMR spectroscopy at various temperatures (40, 50 and $60{ }^{\circ} \mathrm{C}$ for cis-cyclooctene; 50 and $60{ }^{\circ} \mathrm{C}$ fornorbornene) using a five-minute interval. Samples of catalysts $\left(1.7 \times 10^{-3} \mathrm{mmol}, 1.0 \mathrm{mg}\right.$ of Mo1 or 1.2 $\mathrm{mg}$ of W1 $)$ were mixed in solutions of TBHP $(0.40 \mathrm{mmol}, 39 \mu \mathrm{l})$ and substrate $(0.20 \mathrm{mmol}, 26$ of $\mu 1$ of $\mathbf{S 1}$ or 18.8 $\mathrm{mg}$ of S3) in $0.6 \mathrm{ml}$ of $\mathrm{CDCl}_{3}$. 1,2- $\mathrm{C}_{2} \mathrm{H}_{4} \mathrm{Cl}_{2}(10 \mu \mathrm{l})$ was used as an internal standard. The oxidant:olefin:catalyst ratio was 210:110:1. In all experiments, the yields were calculated upon the integrated intensities of substrate olefin and product epoxide spectra. The control experiments were carried out without any catalyst in which case no reaction was observed. In the oxotransfer reactions, $0.20 \mathrm{mmol}(42 \mathrm{mg}$ ) of benzoin was dissolved in $0.6 \mathrm{ml}$ of DMSO $-\mathrm{d}_{6}$ in a NMR tube and then treated with catalyst $\left(1.7 \times 10^{-3} \mathrm{mmol}\right.$, Mo1: $1.0 \mathrm{mg}$; W1: $\left.1.2 \mathrm{mg}\right)$. The reaction mixtures were kept at $100{ }^{\circ} \mathrm{C}$ for $20 \mathrm{~h}$ and subsequently cooled to the room temperature. $1,2-\mathrm{C}_{2} \mathrm{H}_{4} \mathrm{Cl}_{2}(10 \mu \mathrm{l})$ was added as an internal standard and conversion of benzoin to benzil was detected by ${ }^{1} \mathrm{H}$ NMR. Detected yield of benzil was $60 \%$ for Mo1 and $26 \%$ for W1.

\section{Results and discussions}

\subsection{Catalyst preparation and characterisation}

In this study, simple metallate salts were used as inexpensive starting materials for epoxidation catalyst. The stoichiometric amounts of metal precursors $\mathrm{Na}_{2} \mathrm{MO}_{4} \cdot 2 \mathrm{H}_{2} \mathrm{O}(\mathrm{M}=\mathrm{Mo}, \mathrm{W})$ and amine bisphenol $\mathrm{H}_{2} \mathrm{ONO}^{\mathrm{tBu}}$ were mixed in $\mathrm{MeOH}$ in the presence of acetic acid, the reaction mixtures were allowed to reflux for two hours and then cooled to the room temperature. Yellow Mo1 crystallised in a $63 \%$ yield at room temperature, whereas colourless W1 crystallised in a $53 \%$ yield at $5{ }^{\circ} \mathrm{C}$. The crystalline products are made of distinct complex units $\left[\mathrm{MO}_{2}\left(\mathrm{ONO}^{\mathrm{tBu}}\right)(\mathrm{MeOH})\right]$, which crystallise together with one molecule of methanol. The IR and ${ }^{1} \mathrm{H}$ NMR spectra of Mo1 were identical to those found earlier by us [19], whereas the spectra of W1 and Mo1 were closely related 
as expected for an isostructural compound. The main differences are seen in the IR spectra, which show two distinctive absorption maxima for $\mathrm{MO}_{2}{ }^{2+}$ moiety in the expected region. The symmetric and asymmetric stretches are observed at 940 and $887 \mathrm{~cm}^{-1}$ for $\mathbf{M o 1}$ and at 957 and $893 \mathrm{~cm}^{-1}$ for $\mathbf{W 1}$, respectively.

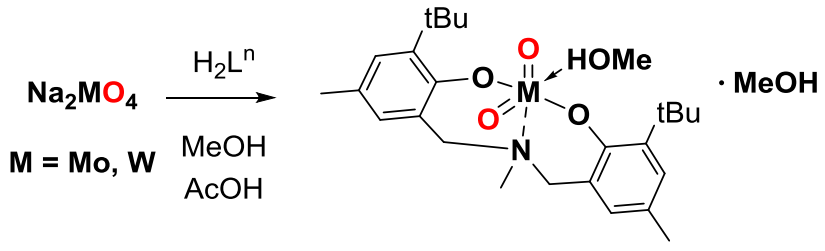

Scheme 1. Preparation of the catalysts.

The X-ray single crystal analysis of $\mathbf{W 1}$ reveal that the solid complex is formed of mononuclear units, in which the aminobis(phenolate) is coordinated to the dioxotungsten(VI) ion as a tridentate ligand. A methanol molecule trans to the oxo group completes the distorted octahedral coordination sphere (see Fig. 1). Another methanol molecule is attached to the complex unit by a hydrogen bond. Uncoordinated MeOH molecule forms an H-bond with terminal oxygen atoms $\mathrm{O} 1(\mathrm{H} \cdots \mathrm{O}$ distance is $1.935 \AA$, see Figure $\mathrm{S} 1)$, therefore the $\mathrm{W}-\mathrm{O} 1$ bond is slightly longer than the $\mathrm{W}-\mathrm{O} 2$ bond. The $\mathrm{O}=\mathrm{W}=\mathrm{O}$ angles and the $\mathrm{W}=\mathrm{O}$ bonds are typical for cis-dioxotungsten(VI) complexes. Similarly, the $\mathrm{W}-$ Oaryloxide, $\mathrm{W}-\mathrm{N}$ and $\mathrm{W}-\mathrm{OMeOH}$ distances are comparable with previous results.[13,20,29,30] In general, W1 is isostructural with the equivalent molybdenum compound with only negligible differences in the bonding parameters [19].

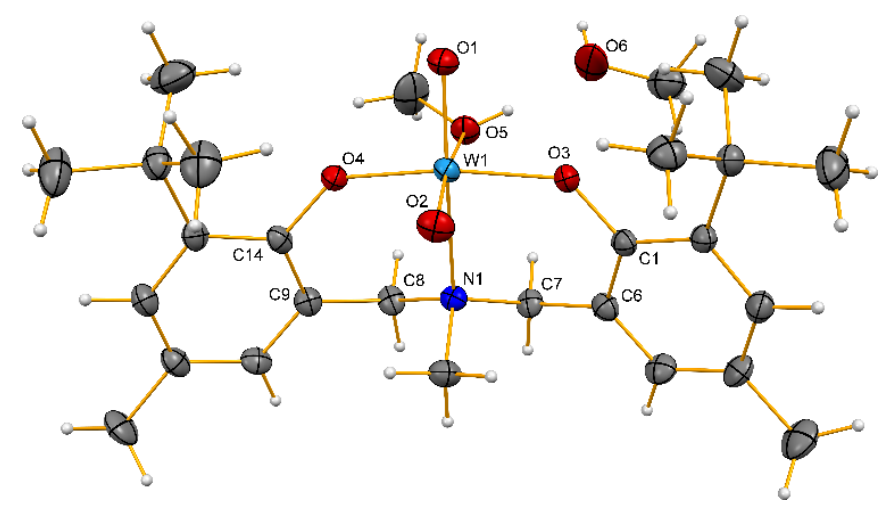

Figure 1. Molecular structure of W1. Selected bond lengths $(\AA)$ and angles $\left(^{\circ}\right)$ : W1-O: 1.733(3); W1-O2: 1.705(3); W1-O3: 1.928(3); W1-O4: 1.928(3); W1-O5: 2.320(3); W1-N1: 2.419(4); O1-W1-O2: 104.26(17); O3-W1-O4: 153.50(14); O1-W1-N1: 166.06(15); O2-W1-O5:167.79(15) 


\subsection{Catalytic activities}

Complexes Mo1 and W1 were screened in the catalytic epoxidation of four different olefinic substrates i.e. ciscyclooctene (S1), cyclohexene (S2), norbornene (S3) and styrene (S4) (Scheme 2) using two equivalents of TBHP (Table 1, entries $1-8$ ) or $\mathrm{H}_{2} \mathrm{O}_{2}$ (Table 1, entries 9 -12) as oxidants (Scheme 3a). The reaction mixtures were analysed by ${ }^{1} \mathrm{H}$ NMR while the yields were calculated upon the integrated intensities of substrate olefin and product epoxide spectra (Table 2, entries 13 -17). Only selectivity towards epoxide formation is reported and attempts to identify other products were not made.

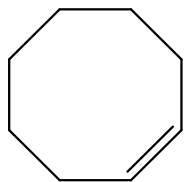

S1<smiles>C1=CCCCC1</smiles>

S2

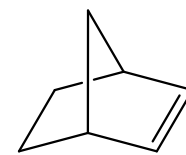

S3<smiles>C=Cc1ccccc1</smiles>

S4

Scheme 2. Substrates for the oxidation reactions<smiles>NC=CCO</smiles>

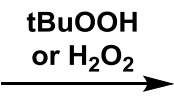<smiles>C[C@@H]1O[C@@H]1C</smiles>

(a)
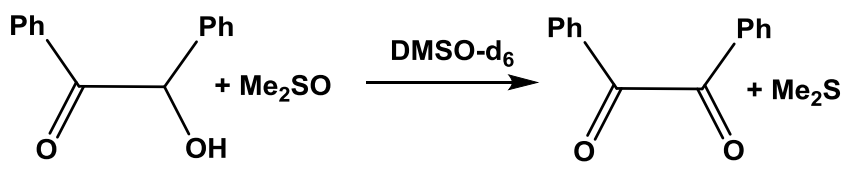

(b)

Scheme 3. Studied epoxidation (a) and oxo transfer (b) reactions.

Table 1. Catalytic activities of Mo1 and W1.

\begin{tabular}{|l|l|l|l|l|l|}
\hline Entry $^{\mathrm{a}}$ & catalyst & substrate & oxidant & conversion (selectivity) [\% & TON $^{\mathrm{b}}$ \\
\hline 1 & Mo1 & S1 & TBHP & $51(100)$ & 107 \\
\hline 2 & Mo1 & S2 & TBHP & $45(38)$ & 36 \\
\hline 3 & Mo1 & S3 & TBHP & $42(90)$ & 80 \\
\hline 4 & Mo1 & S4 & TBHP & $5(60)$ & 6 \\
\hline 5 & W1 & S1 & TBHP & $2(100)$ & 4 \\
\hline 6 & W1 & S2 & TBHP & - & - \\
\hline 7 & W1 & S3 & TBHP & $12(100)$ & 25 \\
\hline 8 & W1 & S4 & TBHP & - & - \\
\hline 9 & Mo1 & S1 & $\mathrm{H}_{2} \mathrm{O}_{2}$ & $15(100)$ & 32 \\
\hline 10 & Mo1 & S3 & $\mathrm{H}_{2} \mathrm{O}_{2}$ & $4(100)$ & 4 \\
\hline
\end{tabular}




\begin{tabular}{|l|l|l|l|l|l|}
\hline 11 & W1 & S1 & $\mathrm{H}_{2} \mathrm{O}_{2}$ & $11(100)$ & 23 \\
\hline 12 & W1 & $\mathbf{S 3}$ & $\mathrm{H}_{2} \mathrm{O}_{2}$ & $3(100)$ & 6 \\
\hline
\end{tabular}

${ }^{\mathrm{a}}$ The reaction conditions: $60^{\circ} \mathrm{C}, 2 \mathrm{~h}, 3.0 \mathrm{mmol}$ of TBHP, $1.5 \mathrm{mmol}$ of olefin, $0.2 \mathrm{ml}$ of $1,2-\mathrm{C}_{2} \mathrm{H}_{4} \mathrm{Cl}_{2}$. The oxidant:olefin:catalyst ratio $=420: 210: 1$.

${ }^{\mathrm{b}}$ Conversion (based on olefin consumption) and selectivity to the epoxide determined by ${ }^{1} \mathrm{H}$ NMR analysis on the crude reaction mixture $\left(1,2-\mathrm{C}_{2} \mathrm{H}_{4} \mathrm{Cl}_{2}\right.$ as an internal standard).

${ }^{c}$ TON calculated as (mol epoxide) $\cdot(\text { mol catalyst })^{-1}$

The epoxidation of cyclooctene S1 using TBHP as oxidant was accomplished by Mo1 (51\% conversion, the turnover number TON $=107)$ with high selectivity. Moreover, Mo1 catalysed the oxidation of norbornene $\mathbf{S 3}$ to corresponding epoxide with TON of 80 . The oxidations of the more challenging substrates cyclohexene and styrene gave the desired epoxides in low yields as the epoxidations were associated with the formation of other oxidation products. In contrast, $\mathbf{W} \mathbf{1}$ showed less activity as only $2 \%$ of cis-cyclooctene $\mathbf{S 1}$ was converted to the corresponding epoxide. W1 had some activity for the selective epoxidation of $\mathbf{S 3}$ but practically no activity for other olefins. The selectivity with substrates $\mathbf{S 1}$ and $\mathbf{S 3}$ using structurally related catalysts equals with the earlier studies by us [13] as well as other groups.[21,35,36] Mo1 and W1 were also tested as catalysts for epoxidation of $\mathbf{S 1}$ and $\mathbf{S 3}$ using aqueous hydrogen peroxide as oxidant instead of TBHP solutions. The reaction was carried out in a two-phase mixture $\left(\mathrm{H}_{2} \mathrm{O}-\mathrm{C}_{2} \mathrm{H}_{4} \mathrm{Cl}_{2}\right)$ and the organic phase was analysed after a two hour reaction. Both complexes showed some activity, whereas no differences between Mo1 and W1 were seen. The activities were lower than in reactions using TBHP, which is possible due to the slow diffusion in a two-phase system. In all epoxidation experiments, the colour of the solutions turned from yellow (Mo1) or colourless (W1) to orange-red during the reaction, which indicates the formation of new metal species or occurrence of redox reactions of the metal centres.

The epoxidation reactions of $\mathbf{S 1}$ and $\mathbf{S 3}$ with catalyst Mo1 were studied in detail by monitoring the reactions via ${ }^{1} \mathrm{H}$ NMR spectroscopy with a five-minute interval (Table 2). The catalyst was mixed in solutions of TBHP and substrate ( $\mathbf{S 1}$ or $\mathbf{S 3}$ ) in $\mathrm{CDCl}_{3}$. The control experiments were carried out without any catalyst in which case no reactions occurred. Conversely, the catalytic reactions started immediately without notable induction times and after 24 hour reactions, the conversions of olefins were practically quantitative in all experiments. The activities of Mo1 for the epoxidation of S1 (Turn-over frequency, TOF $=120,330$ and $660 \mathrm{~h}^{-1}$ at 40,50 and $60{ }^{\circ} \mathrm{C}$, respectively) are comparable to those of a number of dioxomolybdenum(VI) complexes under related conditions, e.g. $\left[\mathrm{MoO}_{2}\left(\mathrm{OSiPh}_{3}\right)\left(2,2^{\prime}\right.\right.$-bipyridine $\left.)\right][35],\left[\mathrm{MoO}_{2} \mathrm{Cl}\left(\mathrm{HC}(\text { bim })_{3}\right)\right] \mathrm{Cl}\left(\mathrm{HC}(\text { bim })_{3}=\right.$ tris(benzimidazolyl $)$ methan $)$ [36] and $\left[\mathrm{MoO}_{2}(\mathrm{acac})\left({ }^{\mathrm{R}} \mathrm{N}, \mathrm{O}\right)\right]\left({ }^{\mathrm{R}} \mathrm{N}, \mathrm{OH}=\right.$ imino-alcohol derivative of $\alpha$-pinene) [37]. The epoxidation activities for 
$\mathbf{S 3}$ were $\left(\mathrm{TOF}=210\right.$ and $410 \mathrm{~h}^{-1}$ at 50 and $60^{\circ} \mathrm{C}$, respectively) were slightly lower than for S1.The kinetic profiles for these epoxidation reactions are presented in a supplementary material.

Table 2. Catalytic activity of Mo1 for the epoxidations of cis-cyclooctene and norbornene.

\begin{tabular}{|l|l|l|l|l|l|}
\hline Entry $^{\mathrm{a}}$ & substrate & catalyst & $\mathrm{T}\left[{ }^{\circ} \mathrm{C}\right]$ & $\mathrm{t}_{1 / 2}[\mathrm{~min}]$ & $\mathrm{TOF}\left[\mathrm{h}^{-1}\right]^{\mathrm{b}}$ \\
\hline 1 & S1 & Mo1 & 40 & - & 120 \\
\hline 2 & S1 & Mo1 & 50 & 20 & 330 \\
\hline 3 & S1 & Mo1 & 60 & 13 & 660 \\
\hline 4 & S3 & Mo1 & 50 & 49 & 210 \\
\hline 5 & S3 & Mo1 & 60 & 30 & 410 \\
\hline
\end{tabular}

${ }^{a}$ The oxidant:olefin:catalyst ratio of 210:110:1.

${ }^{\mathrm{b}}$ TOF calculated at $10 \mathrm{~min}$ reaction as (mol epoxide) $\cdot(\text { mol catalyst })^{-1} \cdot(t / \mathrm{h})^{-1}$. Conversion and yield of the epoxide were determined by ${ }^{1} \mathrm{H}$ NMR analysis on the reaction mixture $\left(1,2-\mathrm{C}_{2} \mathrm{H}_{4} \mathrm{Cl}_{2}\right.$ as an internal standard).

Dioxomolybdenum(VI) and tungsten(VI) complexes are known to catalyse oxotransfer reactions from DMSO to organic substrates or phosphines. [23, 24, 27-29, 38]. Generally, molybdenum-based catalysts are more active in these reactions than their tungsten counterparts. In the present study, the ability of Mo1 and W1 to catalyse oxotransfer reactions was investigated in DMSO solutions using benzoin as the substrate wherein the conversion of benzoin to benzil was monitored by ${ }^{1} \mathrm{H}$ NMR spectroscopy (Scheme 3b). As anticipated, both complexes catalysed oxotransfer from DMSO to benzoin, though the reactions were slow at low temperatures and no reactions were seen at room temperature. The detected yields of oxidized products after $20 \mathrm{~h}$ heating at $100{ }^{\circ} \mathrm{C}$ were $60 \%$ for Mo1 and $26 \%$ for W1 using 1 mol-\% catalyst loading. On the grounds of structurally comparable molybdenum- and tungsten-based catalyst systems, we can assume that the dioxometal(VI) complexes react with benzoin to yield oxometal(IV) complexes and benzil. The central metal ions are then rapidly oxidized back to the initial dioxocompounds with DMSO to complete the catalytic cycle [23, 24]. Although reduced molybdenum and tungsten species are expected to be strongly coloured, only rather weak colour changes were observed during these catalytic reactions indicating that the re-oxidation process of metal is very rapid and/or only small parts of the complexes are actually reacting.

\section{Conclusions}

In conclusion, $\mathrm{Na}_{2} \mathrm{MO}_{4} \cdot 2 \mathrm{H}_{2} \mathrm{O}\left(\mathrm{M}=\mathrm{Mo}\right.$, W) can react with a tridentate $\mathrm{O}_{2} \mathrm{~N}$-type ligand precursor $\left(\mathrm{H}_{2} \mathrm{ONO}^{\mathrm{tBu}}\right)$ to form isostructural dioxometal(VI) complexes $\left[\mathrm{MO}_{2}\left(\mathrm{ONO}^{\mathrm{tBu}}\right)(\mathrm{MeOH})\right] \cdot \mathrm{MeOH}$. The Mo complex catalyses selectively the epoxidation reactions of cis-cyclooctene and norbornene with tert-butyl hydroperoxide and $\mathrm{H}_{2} \mathrm{O}_{2}$, whereas the $\mathrm{W}$ analogue showed lower activities. The Mo complex compares well with a number of 
dioxomolybdenum(VI) complexes used as catalysts for the epoxidation of cyclooctene. Both complexes catalyse also oxygen atom transfer reaction between benzoin and DMSO. These results show the possibility of using aminobisphenolate molybdenum complexes as epoxidation catalysts as well as using molybdenum and tungstenbased catalysts for oxygen atom transfer reactions.

\section{Acknowledgements}

Mr. Vili Gyllström is acknowledged for the syntheses of catalysts and a number of experiments.

\section{References}

1. Holm RH (1990) Coord Chem Rev 100(1): 183-221

2. Hille R (2002) Trends Biochem Sci 27(7): 360-367

3. Romão MJ (2009) Dalton Trans (21): 4053-4068

4. Hille R, Nishino T, Bittner F (2011) Coord Chem Rev 255 (9-10): 1179-1205

5. Hille R (2013) Dalton Trans 42(9): 3029-3042

6. Lorber C, Donahue JP, Goddard CA, Nordlander E, Holm RH (1998) J Am Chem Soc 120(32): 8102-8112

7. Donahue JP, Lorber C, Nordlander E, Holm RH (1998) J Am Chem Soc 120(13): 3259-3260

8. Schulzke C (2011) Eur J Inorg Chem 2011(8): 1189-1199

9. Most K, Hoßbach J, Vidović D, Magull J, Mösch-Zanetti NC (2005) Adv Synth Catal 347(2-3): 463-472

10. Günyar A, Betz D, Drees M, Herdtweck E, Kühn FE (201) J. Mol Catal A: Chem 331(1-2): 117-124

11. Brégeault JM (2003) J Chem Soc Dalton Trans (17): 3289-3302

12. Shylesh S, Jia MJ, Thiel WR (2010) Eur J Inorg Chem 2010(28): 4395-4410

13. Dupé A, Hossain MK, Schachner JA, Belaj F, Lehtonen A, Nordlander E, Mösch-Zanetti NC (2015) Eur J Inorg Chem 2015(21): 3572-3579

14. Kühn FE, Santos AM, Abrantes M (2006) Chem Rev 106(6): 2455-2475

15. Cotton FA, Wilkinson G (1988), Advanced Inorganic Chemistry, 5th Edition, John Wiley \& Sons, New York, pp. 804-847

16. Kletzin A, Adams MWW (1996) FEMS Microbiol Rev 18(1): 5-63

17. Hagedoorn P-L, Hagen WR, Stewart LJ, Docrat A, Bailey S, Garner CD (2003) FEBS Lett 555(3): 606

18. Stewart LJ, Bailey S, Bennett B, Charnock JM, Garner CD, McAlpine AS (2000) J Mol Biol 299(3): 593

19. Lehtonen A, Sillanpää R (2005) Polyhedron, 24(2): 257-265

20. Lehtonen A, Wasberg M, Sillanpää R (2006) Polyhedron 25(3): 767-775 
21. Mayilmurugan R, Traar P, Schachner JA, Volpe M, Mösch-Zanetti NC (2013) Eur J Inorg Chem 2013(21): $3664-3670$

22. Lei X, Chelamalla N (2013) Polyhedron, 49(1): 244-251

23. Hoffman JT, Einwaechter S, Chohan BS, Basu P, Carrano CJ (2004) Inorg Chem 43(24): 7573-7575

24. Millar AJ, Doonan CJ, Smith PD, Nemykin VN, Basu P, Young CG (2005) Chem Eur J 11(11): 3255 3267

25. Jarupatracorn J, Coles MP, Tilley TD (2005) Chem Mater 17(7): 1818 - 1828

26. Hinshaw JC, Peng G, Singh R, Spence JT, Enemark JH, Bruck M, Kristofski J, Merbs SL, Ortega RB, Wexler PA, Inorg Chem 28(25): 4483-4491

27. Wong Y-L, Yan Y, Chan ESH, Yang Q, Mak TCV, Ng DKP (1998) J Chem Soc Dalton Trans (18): 3057 3064

28. Dinda R, Sengupta P, Ghosh S, Sheldrick WS (2003) Eur J Inorg Chem 2003(2): 363 - 369

29. Wong YL, Ma JF, Law WF, Yan Y, Wong WT, Zhang Z-Y, Mak TCW, Ng DKP (1999) Eur J Inorg Chem 1999(2): 313-321

30. Wong Y-L, Tong LH, Dilworth JR, Ng DKP, Lee HK (2010) Dalton Trans 39 (19) 4602 - 4611

31. Madeira F, Barroso S, Namorado S, Reis PM, Royo B, Martins AM (2012) Inorg Chim Acta 383: 152 - 156

32. Lehtonen A (2005) Inorg Chem Commun 8(1): 122 - 124

33. Timosheva NV, Chandrasekaran A, Day RO, Holmes RR (1998) Inorg Chem 37(19): 4945 - 4952

34. Salojärvi E, Peuronen A, Sillanpää R, Damlin P, Kivelä H, Lehtonen A (2015) Dalton Trans 44(20): 9409 9416

35. Rezaeifard A, Jafarpour M, Raissi H, Alipour M, Stoeckli-Evans H (2012) Z Anorg Allg Chem 638(6): $1023-1030$

36. Gago S, Balula MS, Figueiredo S, Lopes AD, Valente A, Pillinger M, Gonçalves IS (2010) Appl Catal A Gen 372(1): $67-72$

37. Chahboun G, Brito JA, Royo B, El Amrani MA, Gómez-Bengoa E, Mosquera MEG, Cuenca T, Royo E (2012) Eur J Inorg Chem 2012(17): 2940 - 2949

38. Arzoumanian H (1998) Coor. Chem. Rev 178-180(1): $191-202$ 